\title{
Experimental study to estimate the discharge coefficient over inclined side spillway
}

\author{
Ayat Mehdi kadhim, Faisal A. Majid
}

Civil Engineering Department, Wasit University, Iraq.

**Corresponding author

Submitted: $17 / 5 / 2017$

Accepted: 8/8/2018

\begin{abstract}
Weir is usually used in different hydraulic purposes, mainly for head discharge-water relationship in channels. In this research, the flow has been carried out over the side of spillway using three cases of crest inclination by means of increasing one side of the weir a half centimeter each time with constant crest length equal to $15 \mathrm{~cm}$. This means that the angle $\theta$ equals to $\left(1.91^{\circ}, 3.82^{\circ}\right.$ and $5.71^{\circ}$ ) respectively towards of the flow and is opposite to the flow with decreasing a half centimeter. Also in case of the breadth is horizontal $(\theta=0)$, seven cases have been tested. It is known that the greater amount of discharge occurs when the breadth is horizontal $(\theta=0)$. In case of the inclination of the weir is inclined opposite to the flow direction, the discharge is greater than that of which the weir inclined towards the flow direction for all cases of inclination. The greater discharge was obtained when decreasing the angle, which is opposite to the flow direction. The amount of discharge over the side of weir decreases by increasing the angle of the slope opposite to the direction of the flow and become more decreasing in case the inclination of side weir towards the flow. In case of increasing the angle of inclination in flow direction, the amount of discharge over side weir will be decreased. The effect of Froude number has also studied with the discharge coefficient and found that, they are proportionally related to each other. Also the water surface profile along the side spillway weir is studied and taken under consideration theoretically and experimentally in this research.
\end{abstract}

Key word: Discharge coefficient, Froude number, side spillway, surface profile, Cd.

\section{1- INTRODUCTION}

Side spillway is a hole located on the side of the main channel, which has a crest length and height from the bottom of the channel, to allow a part of excess water to spill over side spillway, when the water level in the channel is higher than the edge of the side spillway. The side spillway is used in the process of irrigation by creating a side opening on the wall of the main channel. It also used to control the level of water in the irrigation channel by disposal the excess water into the sub channel below working as side escape. Also it used in the sanitary engineering to drain the excess of storm water from internal sewage of cities and dispose it to the river. The flow over the side of spillway has considered to be spatially varied flow. It has studied by [1],[2],[3],[4],[5],[6],[7],[8],[9],[10],[11] and [12]. All researchers studied the discharge coefficient over the side spillway and they used different variables, including the length of the side spillway, the height of the weir at the end of the channel and the angle of weir inclination. They also studied the relation between the discharge coefficient and Froude number. The purpose of this study is to know the effect of inclination angle of the side spillway in both with and against the flow direction on the discharge coefficient. Finally, the results of the relation between Froude number and discharge coefficient is taken into consideration.

2- THEORETICAL WORK

If specific energy is considered constant, the energy equation can be used to solve the discharge over the side of the spillway, where the energy equation is [13]:

$$
E=y+z+\frac{v^{2}}{2 g}
$$

By differentiate equation (1), the following equations is obtained [14]

$$
\begin{gathered}
\quad \frac{d H}{d x}=\frac{d z}{d x}+\frac{d y}{d x}+\frac{\alpha}{2 g}\left(\frac{2 Q d Q}{A^{2} d x}-\frac{2 Q^{2}}{A^{3}} \frac{d A}{d x}\right) \\
\text { Where: } \quad \frac{d A}{d x}=\left(\frac{d A}{d y}\right)\left(\frac{d y}{d x}\right)=\frac{T d y}{d x},
\end{gathered}
$$

where $\mathrm{T}$ is the top width of the channel which is equal to the bed width in rectangular channels 


$$
\begin{gathered}
\frac{d z}{d x}=-s o \quad, \text { and } \frac{d H}{d x}=-s f \quad, \text { then equation (2) will become } \\
\frac{d y}{d x}=\frac{s o-s f-\alpha \frac{Q}{g A^{2}} \frac{d Q}{d x}}{1-\alpha \frac{Q^{2} T}{g A^{3}}}
\end{gathered}
$$

Equation (4) is the dynamic equation for spatially varied flow, with decreasing discharge which is almost constant $\alpha=1$ the energy coefficient for steady and unsteady types of flow where:

$\mathrm{T}=$ the surface width,

$s_{r}=$ energy coefficient,

$s_{o}=$ channel bed slope,

$s_{f}=$ energy slope,

and $\mathrm{Q}=$ channel discharge.

Equation (4) is used to know the water profile a long side spillway through the experimental and theoretical results, it is found that the discharge coefficient effected by several factor such as:

$$
\mathrm{Cd}=\mathrm{f}(\mathrm{h}, \mathrm{s}, \theta)
$$

The discharge over weir depend on the height of water over the weir, it is represent theoretical discharge as follows:

$$
Q=\frac{2}{3} \sqrt{2 g} B h^{1.5}
$$

where: $\mathrm{h}=(\mathrm{y}-\mathrm{s})$,

$\mathrm{y}=$ total water height in the channel,

$\mathrm{B}=$ the length of the weir crest,

$\mathrm{S}=$ sill crest height over the channel bed,

and $\mathrm{h}=$ water height over the weir.

The discharge calculation depends on the volume of water spilling over the weir during certain time, which is representing experimental discharge (actual discharge). The discharge coefficient is calculated by dividing experimental discharge by the theoretical discharge

3- EXPERIMENTAL WORK

The experimental work was carried out in the engineering workshop of the college of engineering at Wasit University. A rectangular channel with a $3 \mathrm{~m}$ length, $20 \mathrm{~cm}$ width and $20 \mathrm{~cm}$ depth locally manufactured was used. The channel contains a sharp crested weir made of iron with a constant height $(5 \mathrm{~cm})$ placed at the end of the channel. The channel contains, also, an inclined side spillway $15 \mathrm{~cm}$ long, and $5 \mathrm{~cm}$ in height and located at the center of the channel wall. A movable gate with dimension $(20 \mathrm{~cm}$ wide and $15 \mathrm{~cm}$ height) is used for controlling the inclination of the side weir as shown in Fig. (1). Three tanks were used to store the water. The main tank dimensions are $0.91 \mathrm{~m}$ wide, $0.9 \mathrm{~m}$ long and $1 \mathrm{~m}$ height. The other tanks, where one is fixed below side spillway and the second is fixed below the end of the channel with dimensions of $0.68 \mathrm{~m}$ wide, $0.68 \mathrm{~m}$ long and $1 \mathrm{~m}$ height as shown in fig. (2). The main tank has connected to the pumps to supply the water for the channel and to get a continuation of flow in the channel. The flow in the channel will be changed by controlling a number of pumps operations along the experimental work. Part of the water spill over the side spillway and the other part of flow was continuing to the end of the channel. The actual discharge is usually calculated by means of the volumetric method way which is dividing the amount of spilling water over the weir in certain time required. The theoretical discharge is calculated as a function of the height of water over the weir. Therefore, by dividing the actual discharge on the theoretical discharge to get the discharge coefficient for each case. 


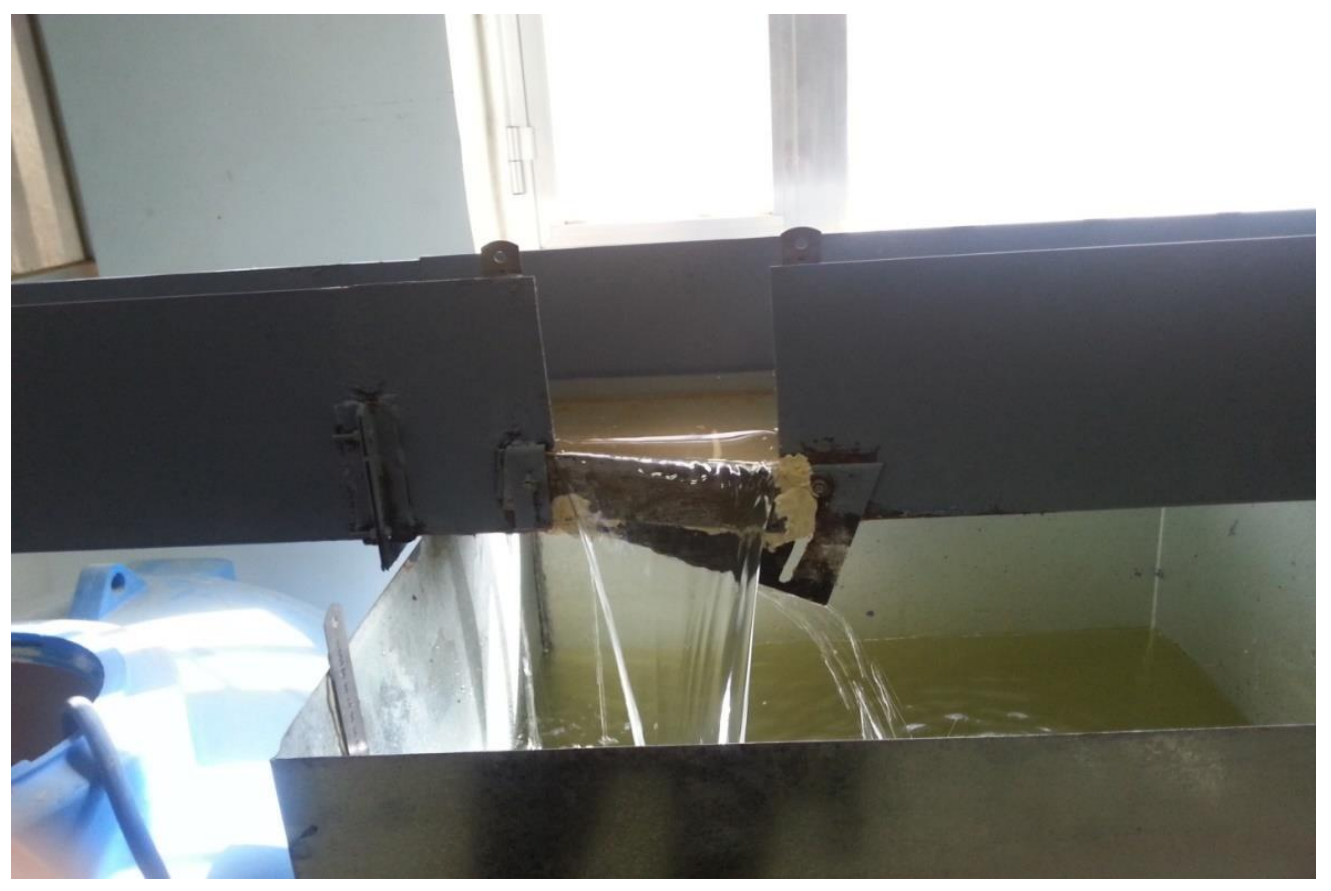

Fig. (1) inclined side spillway opposite to flow direction

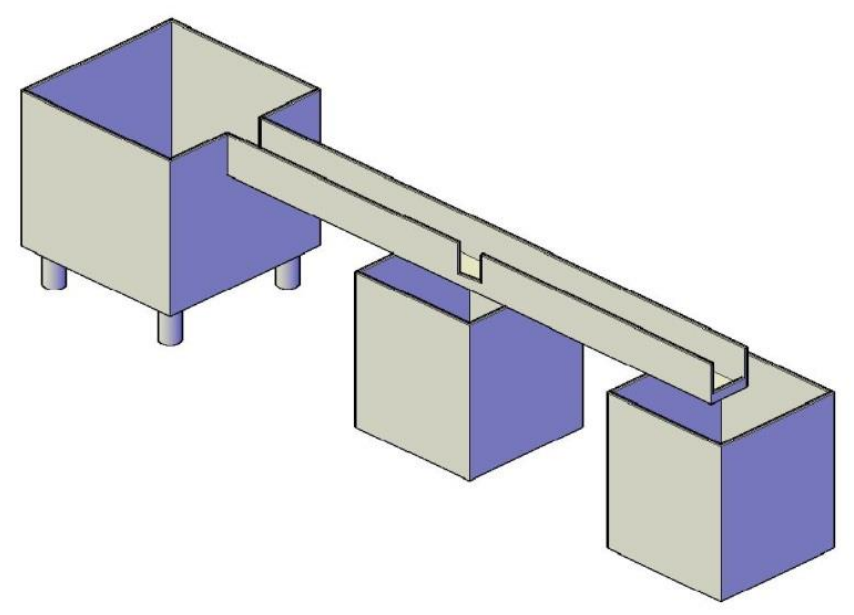

Fig. (2) tanks sequence and channel side spillway

\section{4- RESULTS AND DISCUSSIONS}

The discharge coefficient is calculated as follow:

1. By using equation (6), the theoretical discharge over the side weir is calculated. The average depth of water over the side spillway is measured to be in the equation.

2. The actual discharge was measured depending on the water volume in the tanks below the side weir and at the end of the channel during a certain of period time. Equation (7) calculates the actual discharge.

$$
\mathrm{Q}=\frac{\text { volume }}{\text { time }}
$$


3. Finally, to find the discharge coefficients for both side weir and tail weir of the channel, the results of the experimental discharge is divided by the theoretical discharge.

$$
\mathrm{Cd}=\frac{\text { Qexp }}{\text { Qthe }}
$$

The discharge coefficient was measured five times (which means the discharge in main channel changed five time according to the change in water level in the upstream of channel ) for each case of the three angle of inclination in both directions with and opposite to the channel flow as well as for the horizontal crest. Tables (1), (2) and(3) represent the discharge calculations for inclined side spillway with flow direction $(5-6) \mathrm{cm}$, inclined side spillway opposite to flow direction (5-6) $\mathrm{cm}$ and horizontal side spillway. These tables contain three main column, the first column represent the results of the tank below the side spillway. The second column represents the results of the tank at the end of channel. The third column represents the discharge results of the channel before side spillway (which represents the main supply discharge).The symbols that are mentioned in tables (1), (2) and (3) are:

Yav=the height of water inside the tank

$\mathrm{h}=$ the height of water over the weir

Qsth= theoretical discharge over the weir

Q2th = theoretical discharge over the end weir

Qsact=actual discharge over the side weir

Q2act=actual discharge over the end weir

$\mathrm{Q} 1=$ total discharge in the main channel

$\mathrm{Y} 1=$ height of water in the channel before the weir

$\mathrm{Cd}_{1}=$ discharge coefficient for side weir

$\mathrm{Cd}_{2}=$ discharge coefficient for end weir

$\mathrm{V} 1=$ the velocity in main channel before the side spillway

$\mathrm{Fr}_{1}=$ Froude number in the main channel before side spillway 
Table (1) inclined side spillway with the flow direction (5-6) $\mathrm{cm}$

\begin{tabular}{|c|c|c|c|c|c|c|c|c|c|c|c|c|c|}
\hline \multicolumn{5}{|c|}{ Tank below side spillway } & \multicolumn{5}{|c|}{ Tank below the end of channel } & \multicolumn{4}{|c|}{ Discharge and velocity before side spill } \\
\hline $\begin{array}{l}\mathrm{H}=(\mathrm{y}-\mathrm{s}) \\
\mathrm{m} * 10^{-3}\end{array}$ & $\begin{array}{l}\text { Qsth } \\
m^{3} / s \\
* 10^{-4}\end{array}$ & $\begin{array}{l}\text { Yav } \\
\text { M }\end{array}$ & $\begin{array}{l}\text { Qsact } \\
m^{3} / s \\
* 10^{-4}\end{array}$ & $\mathrm{Cd}_{1}$ & $\begin{array}{l}\mathrm{H}=(\mathrm{y}-\mathrm{s}) \\
\mathrm{m} * 10^{-3}\end{array}$ & $\begin{array}{l}\text { Q2th } \\
m^{3} / s \\
* 10^{-4}\end{array}$ & $\begin{array}{l}\text { Yav } \\
\mathrm{m}\end{array}$ & $\begin{array}{l}\text { Q2act } \\
m^{3} / s \\
* 10^{-4}\end{array}$ & $\mathrm{Cd}_{2}$ & $\begin{array}{l}\text { Q1(Qsact+Q2 } \\
\text { act) } \\
m^{3} / s * 10^{-4}\end{array}$ & $\begin{array}{l}\text { Y1 } \\
\text { m }\end{array}$ & $\begin{array}{l}\mathrm{V} 1 \\
\mathrm{~m} / \mathrm{s} \\
* 10^{-3}\end{array}$ & $\mathrm{Fr}_{1}$ \\
\hline 4.5 & 1.337 & 0.027 & 0.416 & 0.31 & 5.2 & 2.212 & 0.068 & 1.048 & 0.47 & 1.464 & 0.075 & 9.76 & 0.0113 \\
\hline 4 & 1.121 & 0.024 & 0.369 & 0.33 & 5 & 2.085 & 0.06 & 0.924 & 0.44 & 1.293 & 0.07 & 9.235 & 0.011 \\
\hline 3.7 & 0.997 & 0.018 & 0.277 & 0.27 & 4.6 & 1.84 & 0.055 & 0.847 & 0.46 & 1.124 & 0.065 & 8.64 & 0.01 \\
\hline 3.5 & 0.917 & 0.014 & 0.215 & 0.23 & 4.2 & 1.605 & 0.045 & 0.693 & 0.43 & 0.908 & 0.06 & 7.566 & 0.0098 \\
\hline 3 & 0.727 & 0.01 & 0.154 & 0.21 & 4 & 1.492 & 0.035 & 0.539 & 0.36 & 0.693 & 0.055 & 6.3 & 0.0085 \\
\hline
\end{tabular}

Table (2) inclined side spillway opposite to the flow direction (5-6) $\mathrm{cm}$

\begin{tabular}{|c|c|c|c|c|c|c|c|c|c|c|c|c|c|}
\hline \multicolumn{5}{|c|}{ Tank below side spillway } & \multicolumn{5}{|c|}{ Tank below the end of channel } & \multicolumn{4}{|c|}{ Discharge and velocity before side spillway } \\
\hline $\begin{array}{l}\mathrm{H}=(\mathrm{y}-\mathrm{s}) \mathrm{m} \\
* 10^{-3}\end{array}$ & $\begin{array}{l}\text { Q2th } \\
m^{3} / s \\
* 10^{-4}\end{array}$ & $\begin{array}{l}\text { Yav } \\
M\end{array}$ & $\begin{array}{l}\text { Qsact } \\
m^{3} / s \\
* 10^{-4}\end{array}$ & $\mathrm{Cd}_{1}$ & $\begin{array}{l}\mathrm{H}=(\mathrm{y}-\mathrm{s}) \mathrm{m} \\
* 10^{-3}\end{array}$ & $\begin{array}{l}\text { Q2th } \\
m^{3} / s \\
* 10^{-4}\end{array}$ & $\begin{array}{l}\text { Yav } \\
\text { M }\end{array}$ & $\begin{array}{l}\text { Q2act } \\
m^{3} / s \\
* 10^{-4}\end{array}$ & $\mathrm{Cd}_{2}$ & $\begin{array}{l}\text { Q1(Qsact } \\
+ \text { Q2act) } \\
\mathrm{m}^{3} / \mathrm{s} \\
* 10^{-4}\end{array}$ & $\begin{array}{l}\mathrm{Y} 1 \\
\mathrm{~m}\end{array}$ & $\begin{array}{l}\mathrm{V} 1 \\
\mathrm{~m} / \mathrm{s}\end{array}$ & Fr1 \\
\hline 4.8 & 1.473 & 0.033 & 0.508 & 0.34 & 5 & 2.085 & 0.065 & 1 & 0.47 & 1.508 & 0.075 & 0.01 & 0.0116 \\
\hline 4.5 & 1.337 & 0.027 & 0.416 & 0.31 & 4.7 & 1.901 & 0.058 & 0.894 & 0.47 & 1.31 & 0.07 & 0.0093 & 0.0112 \\
\hline 4.2 & 1.206 & 0.023 & 0.354 & 0.29 & 4.2 & 1.605 & 0.05 & 0.77 & 0.48 & 1.124 & 0.065 & 0.0086 & 0.0107 \\
\hline 4 & 1.121 & 0.02 & 0.308 & 0.27 & 4 & 1.492 & 0.04 & 0.616 & 0.41 & 0.924 & 0.06 & 0.0077 & 0.01 \\
\hline 3.5 & 0.917 & 0.016 & 0.246 & 0.26 & 3.5 & 1.221 & 0.032 & 0.493 & 0.4 & 0.739 & 0.055 & 0.0067 & 0.0091 \\
\hline
\end{tabular}


Table (3) horizontal side spillway

\begin{tabular}{|c|c|c|c|c|c|c|c|c|c|c|c|c|c|}
\hline \multicolumn{5}{|c|}{ Tank below side spillway } & \multicolumn{5}{|c|}{ Tank below the end of channel } & \multicolumn{4}{|c|}{ Discharge and velocity before side spillway } \\
\hline $\begin{array}{c}\mathrm{H}=(\mathrm{y}-\mathrm{s}) \mathrm{m} \\
* 10^{-3}\end{array}$ & $\begin{array}{l}\text { Qsth } \\
m^{3} / \mathrm{s} \\
* 10^{-4}\end{array}$ & $\begin{array}{c}\text { Yav } \\
\text { M }\end{array}$ & $\begin{array}{l}\text { Qsact } \\
m^{3} / \mathrm{s} \\
* 10^{-4}\end{array}$ & $\mathrm{Cd}_{1}$ & $\begin{array}{c}\mathrm{H}=(\mathrm{y}-\mathrm{s}) \mathrm{m} \\
* 10^{-3}\end{array}$ & $\begin{array}{l}\text { Q2th } \\
m^{3} / s \\
* 10^{-4}\end{array}$ & $\begin{array}{c}\text { Yav } \\
\text { M }\end{array}$ & $\begin{array}{l}\text { Q2act } \\
m^{3} / s \\
* 10^{-4}\end{array}$ & $\mathrm{Cd}_{2}$ & $\begin{array}{c}\mathrm{Q} 1=(\mathrm{Q} s a c t+\mathrm{Q} 2 \mathrm{a} \\
\mathrm{c}) \\
\mathrm{m}^{3} / \mathrm{s} * 10^{-4}\end{array}$ & Y1 & $\begin{array}{l}\mathrm{V} 1 \\
\mathrm{~m} / \mathrm{s}\end{array}$ & Fr1 \\
\hline 5.7 & 1.906 & 0.061 & 0.940 & 0.49 & 5 & 2.086 & 0.063 & 0.971 & 0.46 & 1.911 & 0.075 & 0.0127 & 0.0148 \\
\hline 5.4 & 1.757 & 0.05 & 0.77 & 0.44 & 4.5 & 1.781 & 0.055 & 0.847 & 0.47 & 1.617 & 0.07 & 0.0115 & 0.0138 \\
\hline 5 & 1.566 & 0.043 & 0.663 & 0.42 & 4 & 1.492 & 0.042 & 0.647 & 0.43 & 1.31 & 0.065 & 0.01 & 0.0125 \\
\hline 4.8 & 1.473 & 0.037 & 0.57 & 0.38 & 3.5 & 1.221 & 0.036 & 0.554 & 0.45 & 1.124 & 0.06 & 0.0093 & 0.0121 \\
\hline 4.3 & 1.249 & 0.035 & 0.539 & 0.43 & 3 & 0.97 & 0.02 & 0.308 & 0.31 & 0.847 & 0.055 & 0.0077 & 0.01 \\
\hline
\end{tabular}


Form the results and Figures (3), (4) and (5) of all cases, the discharge coefficient reached a maximum value in case of horizontal crest side spillway where $\mathrm{cd}=0.61$ whereas the minimum value of discharge coefficient $\mathrm{cd}=0.43$ in case of inclined side spillway with flow direction for the inclination angle (5.71) (5$6.5) \mathrm{cm}$. The discharge coefficient in case of opposite to flow direction is larger than which of with flow direction for the same angle of inclination. It is clear from the obtained results that when the angle of inclination increases the discharge coefficient decreases. The discharge in the tail of main channel is greater than the discharge over the side spillway for all cases except in the case of horizontal side spillway where, the discharge over side spillway $(\mathrm{cd}=61)$ is greater than the discharge over the end weir $(\mathrm{cd}=0.58)$.

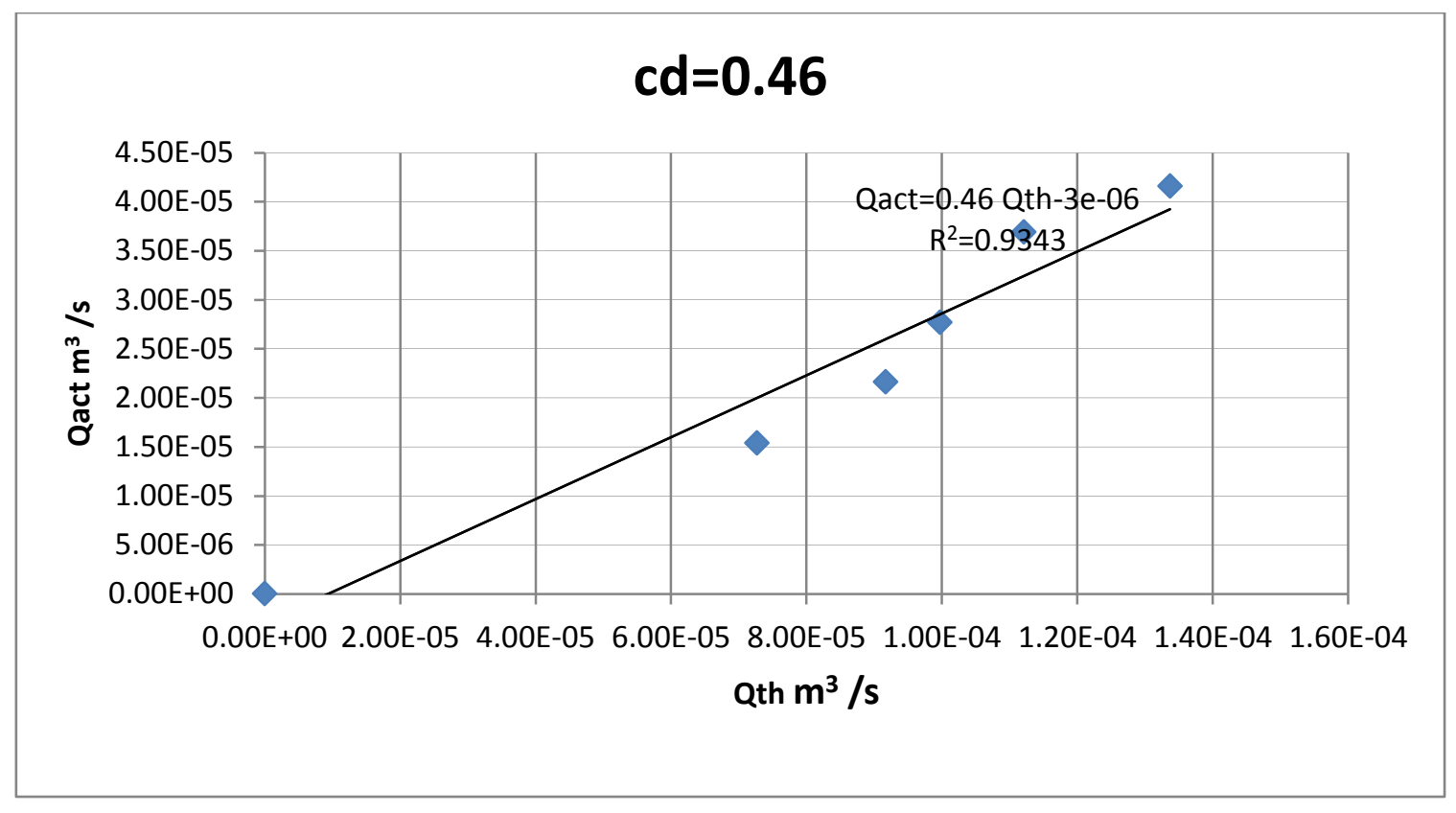

Fig. (3) the relation between theoretical discharge and actual discharge to find discharge coefficient for inclined side spillway with flow direction $(5-6) \mathrm{cm}$

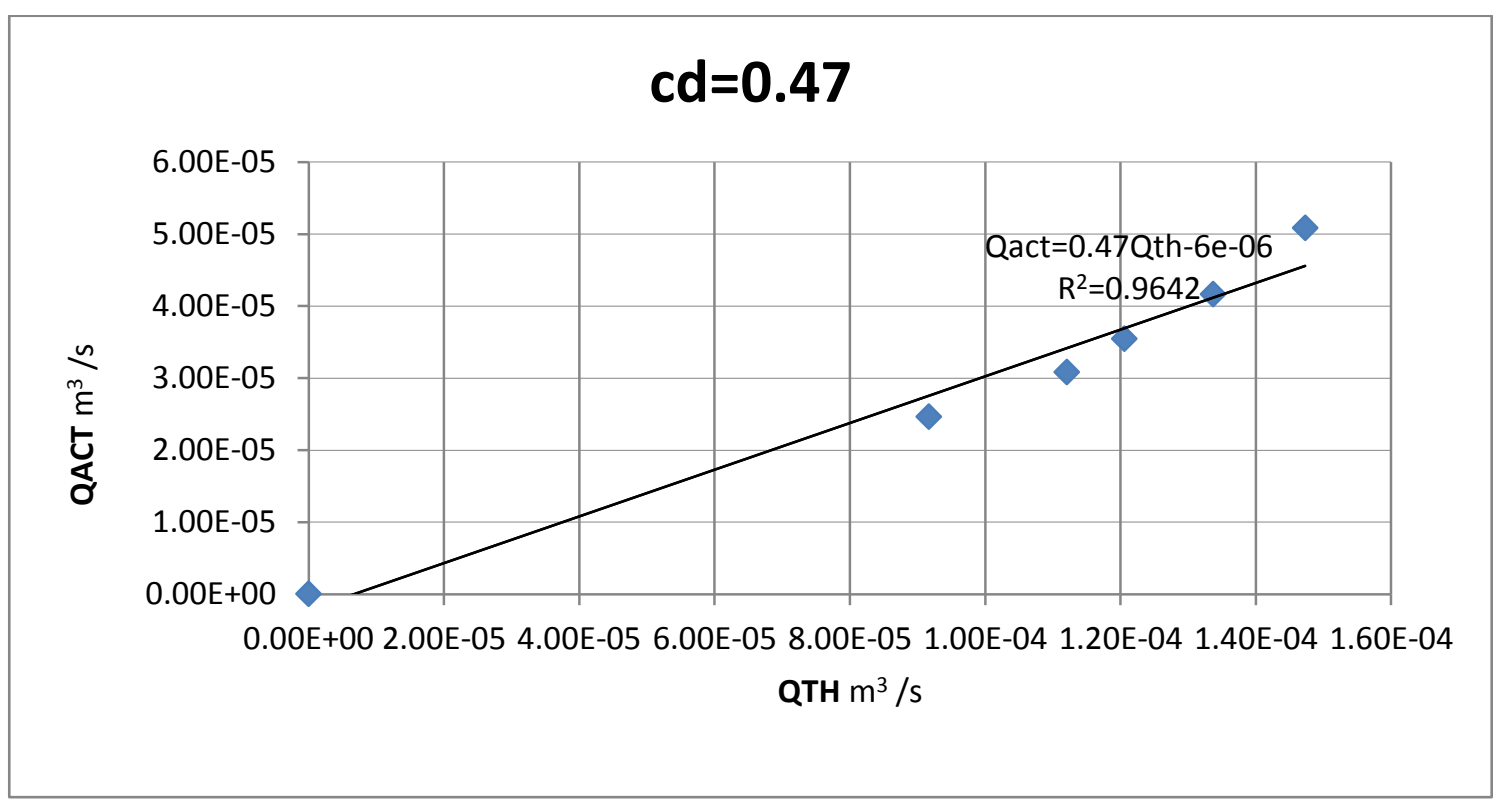

Fig (4) the relation between theoretical discharge and actual discharge to find discharge coefficient for inclined side spillway opposite to flow direction $(5-6) \mathrm{cm}$ 


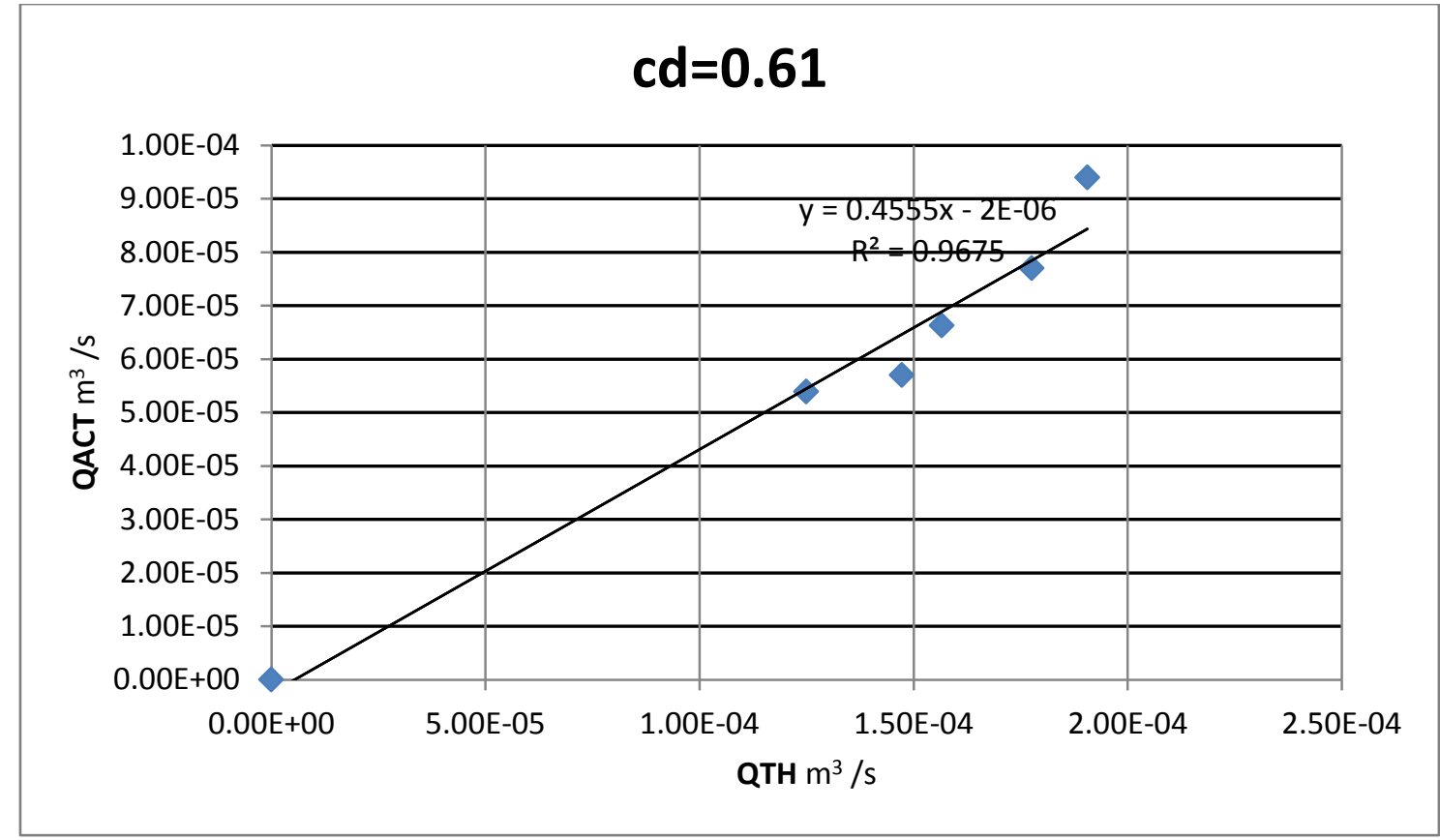

Fig. (5) the relation between theoretical discharge and actual discharge to find discharge coefficient for horizontal side weir

From Figures (6) and (7) it is clear that the ratio of the discharge over side weir to main discharge (Qs/Q1) for inclined side spillway opposite to flow direction larger than in the case of inclined side spillway with flow direction for the same angles.

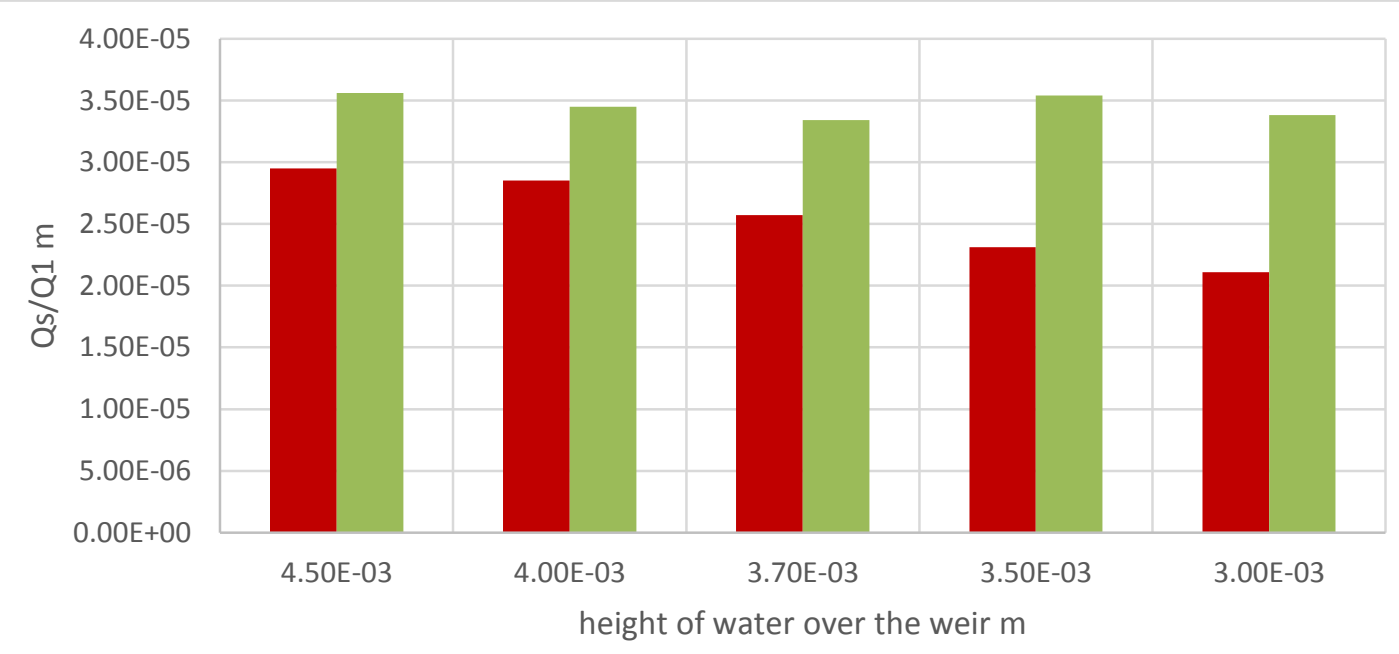

— inclined side weir in flow directin (5-6) $\quad$ inclined side weir opposite to flow direction (5-6)

Fig. (6) the relation between Qs/Q1 and height of water over the weir for inclined side spillway with flow direction (5-6) $\mathrm{cm}$ 


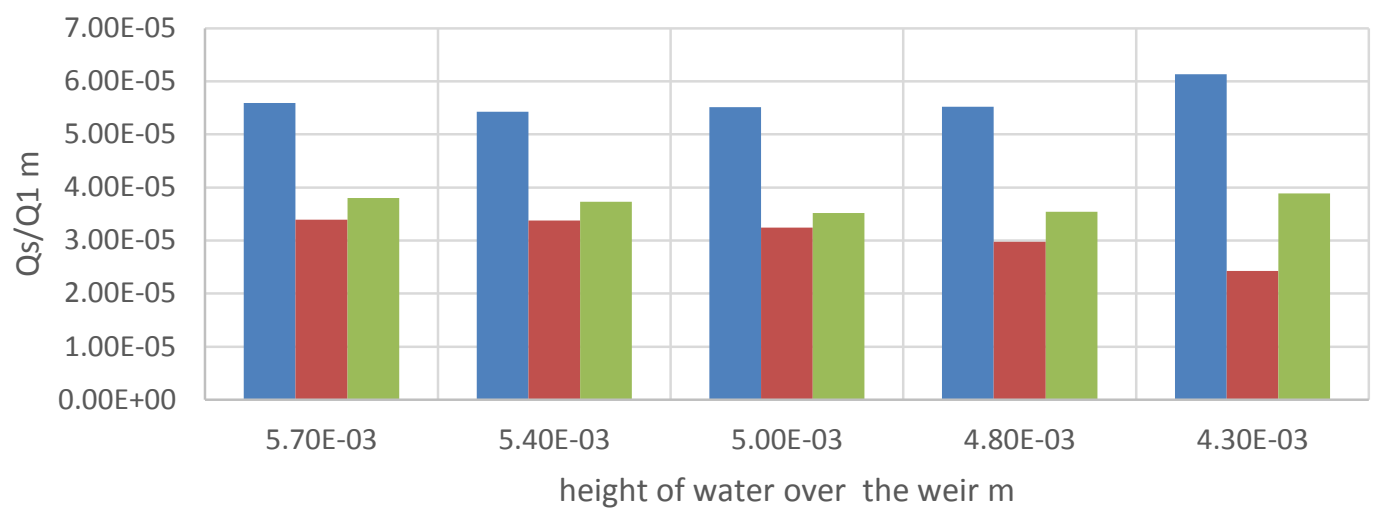

\author{
rectangular side weir \\ — inclined side weir in flow direction (5-5.5) \\ inclined side weir opposite to flow direction (5-5.5)
}

Fig. (7) the relation between $\mathrm{Qs} / \mathrm{Q} 1$ and height of water over the weir for horizontal side weir

Figures (8) and (9) show the relation between cd and $\Theta$ for inclined side spillway. The discharge coefficient affected by several factor. The important one is the angle of inclination $\Theta$; this relation can be represented by equation (9) for inclined side spillway with flow direction.

$\mathrm{Cd}=0.5899 \theta+0.0105$

and equation (10) for inclined side spillway opposite to flow direction.

$\mathrm{Cd}=0.5432 \theta+0.0132$

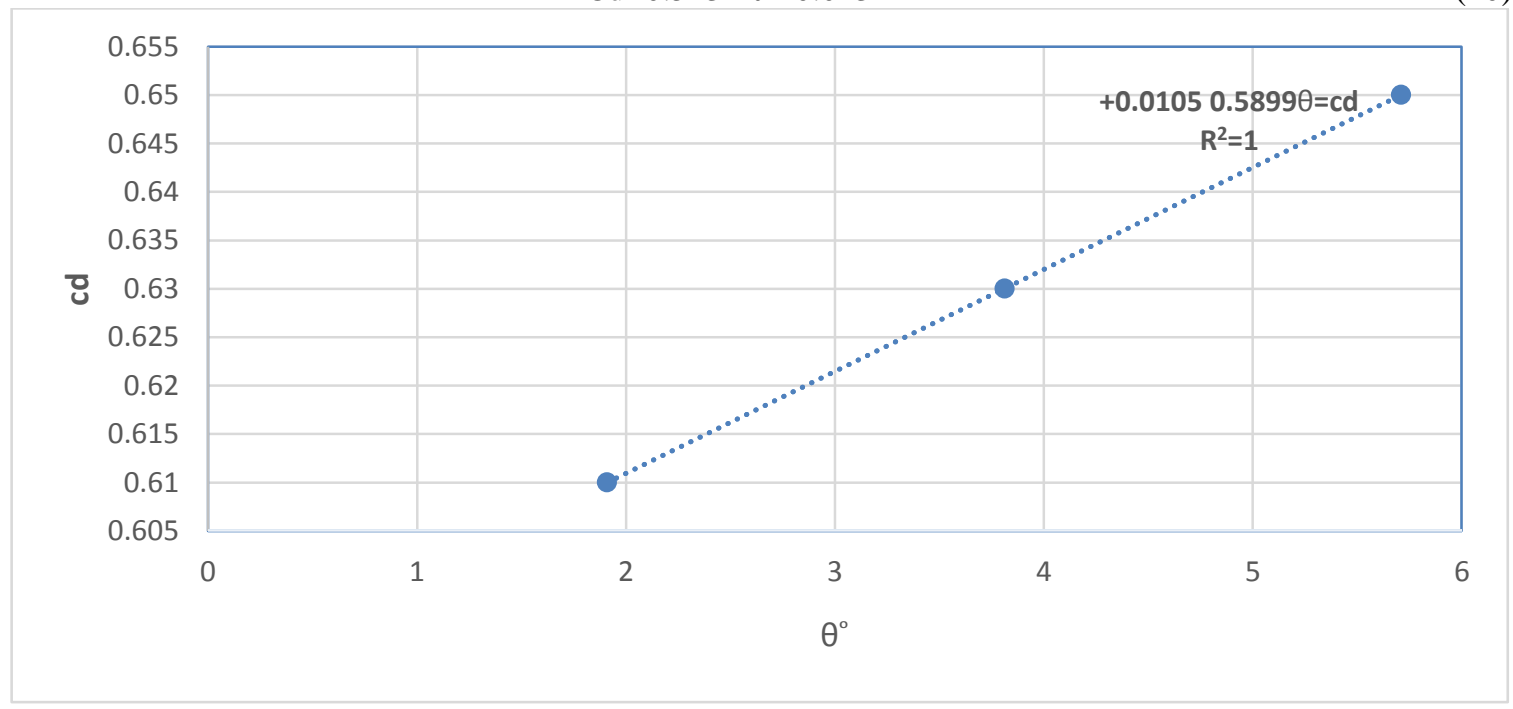

Fig. (8) the relation between cd and inclination angle for inclined side spillway with flow direction 


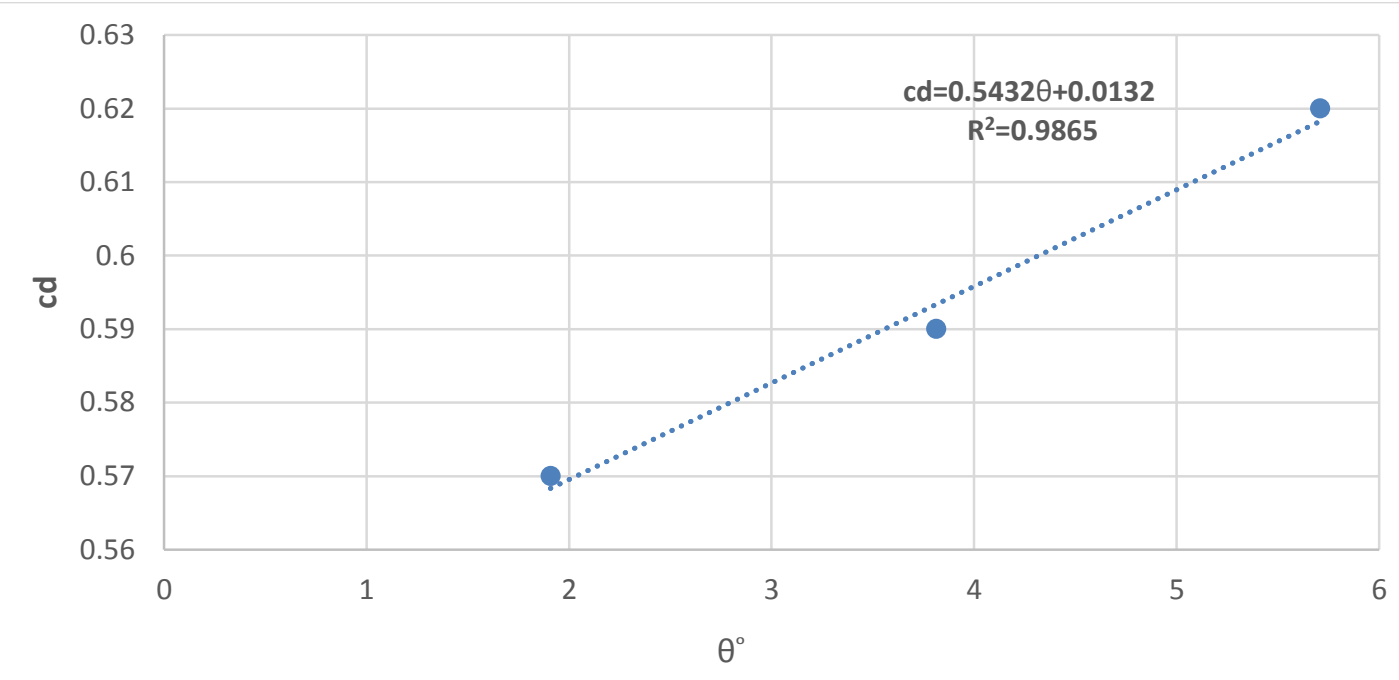

Fig. (9) the relation between cd and inclination angle for inclined side spillway opposite to flow direction

\section{5- CONCLUSION}

The discharge coefficient was calculated for the side spillway depending on inclination of weir crest angle with flow direction and opposite to the flow direction, and it was found that:

1. The large discharge occurred when the crest for the side spillway was level $(\theta=0)$ if compared with the other cases of inclined side spillways.

2. The discharge over side spillway is greater than the discharge in the tail of the main channel for case $(\theta=0)$ horizontal side spillway.

3. In the case of inclined side spillway, the best discharge occurred when the crest inclined opposite to flow direction with smaller angle $\theta=1.91$, of inclination $(5-5.5 \mathrm{~cm})$. The minimum discharge occurred when side spillway inclined with the direction of flow for large angle $(\theta=5.71)$ of inclination $(5-6.5 \mathrm{~cm})$. It means that the results of $\left(\frac{Q s}{Q 1}\right)$ when side spillway inclined with flow direction are larger than results obtained from the side spillway inclined opposite to flow direction.

\section{REFERENCE}

[1] Al_neima Ilham Fatheel Kasim "prediction of discharge cofficient for inclined weirs " April 1983

[2] Raju Ranga Prasad B.,K.G., and Gupta S.K. "Side weir in Rectangular channel”,Jouarnal of hydraulic division ,A.S.C.E. ,Vol. 105, No.HY5, May. 1979 ,PP. 547-554.

[3] Al_rawi Ayad Abdul_Aziz "Sharp Crested Inclined Side Spillway" Building and construction department .university., of technology ., 1988.

[4] Mohammed, A. Y. “ Numerical analysis of flow over side weir" Journal of King Saud University-Engineering Sciences, 27(1), 37-42,(2015).

[5] Borghei, S. M., Vatannia, Z., Ghodsian, M., \& Jalili, M. R. "Oblique rectangular sharp-crested weir". In Proceedings of the Institution of Civil Engineers-Water and Maritime Engineering(Vol. 156, No. 2, pp. 185-191). Thomas Telford Ltd (2003, June).

[6] Samiee, S., Heidarpour, M., \& Bagheri, S. "Flow characteristics of rectangular sharp-crested side weirs in the presence of guide vanes". ISH Journal of Hydraulic Engineering, 22(1), 109-114, (2016).

[7] Seyedian, S. M., Jalili Ghazizadeh, M., \& Tareghian, R. "Determining side-weir discharge coefficient using Anfis". In Proceedings of the Institution of Civil Engineers-Water Management(Vol. 167, No. 4, pp. 230-237). Thomas Telford Ltd , (2014, April).

[8] Bijankhan, M., \& Ferro, V. "Experimental Study and Numerical Simulation of Inclined Rectangular Weirs". Journal of Irrigation and Drainage Engineering, 144(7), 04018012 , (2018). 10

[9] Swamee, P. K., Pathak, S. K., \& Ali, M. S. "Side-weir analysis using elementary discharge coefficient". Journal of irrigation and drainage engineering, 120(4), 742-755, (1994).

[11] El-Khashab , A \& Smith "Experimenetal Investigation of flow over side weir "Journal of Hydraulic division ,A.S.C.E. ,Vol. 102, NO. HY9, Sep . 1976, PP. 1255-1268. [10] Aydin, I., 
Altan-Sakarya, A. B., \& Sisman, C." Discharge formula for rectangular sharp-crested weirs". Flow Measurement and Instrumentation, (2011), 22(2), 144-151.

[12] Karim, M. Gibrahim, a., \& Azhee "Simulation of local scour development downstream of broad-crested weir with inclined apron". Avrupa Bilim ve Teknoloji Dergisi, (Özel Sayı-Special Issue). (2017), 57-61.

[13] Keshavarzi, A., \& Ball, J." Discharge coefficient of sharp crested side weir in trapezoidal channel with different side-wall slopes under subcritical flow conditions". Irrigation and drainage, (2014), 63(4), 512-522.

[14] Bonakdari, H., \& Zaji, A. H." New type side weir discharge coefficient simulation using three novel hybrid adaptive neuro-fuzzy inference systems". Applied Water Science, (2018), 8(1), 10. 